\title{
Characterization of Seiridium spp. Associated with Cypress Canker Based on B-Tubulin and Histone Sequences
}

Irene Barnes, Jolanda Roux, Michael J. Wingfield, Department of Microbiology and Plant Pathology, Tree Pathology Co-operative Programme (TPCP), Forestry and Agricultural Biotechnology Institute (FABI), University of Pretoria, Pretoria, 0002, South Africa; Martin P. A. Coetzee and Brenda D. Wingfield, Department of Genetics, TPCP, FABI, University of Pretoria

\begin{abstract}
Barnes, I., Roux, J., Wingfield, M. J., Coetzee, M. P. A., and Wingfield, B. D. 2001. Characterization of Seiridium spp. associated with cypress canker based on B-tubulin and histone sequences. Plant Dis. 85:317-321.

Cypress canker is a serious disease that has devastated Cupressus spp. in many parts of the world. In Mediterranean Europe it has caused the deaths of millions of trees. Three species of Seiridium, S. cardinale, S. cupressi, and S. unicorne, are associated with cypress canker. Considerable debate surrounds the taxonomic status of these fungi. They have been viewed as a single morphologically variable species, three distinct taxa; or two species based on the presence or absence of conidial appendages. Studies based on ribosomal DNA (ITS1, ITS2, and 5.8S gene) sequence failed to separate the cypress canker fungi. In an attempt to distinguish between the species associated with cypress canker we used histone and partial $\beta$-tubulin sequences of fourteen isolates of Seiridium spp. from cypress. Analysis of sequence data showed Seiridium isolates from Cupressus spp., residing in two major clades. One clade accommodated S. unicorne isolates from Portugal and South Africa. The other major clade consisted of two subclades containing non-appendaged $S$. cardinale isolates. We believe the larger second clade, represents the cypress canker pathogens while the other clade contains the less pathogenic $S$. unicorne, which has a host range beyond Cupressus. This study thus provides strong evidence to support previous morphological data suggesting three distinct species are associated with cypress canker.
\end{abstract}

Additional keyword: phylogeny

Cypress canker is a serious disease, especially in the Mediterranean where it threatens complete destruction of Cupressus spp. (7). The cypress canker pathogens are Coelomycetes belonging to the genus Seiridium Nees ex Fr. Three species of Seiridium are associated with cypress canker. S. cardinale (Wagener) Sutton and Gibson, was first reported in the United States (18) and then New Zealand. It is now found in many parts of the world, including Mediterranean Europe (7). $S$. cupressi (Guba) Boesewinkel is believed to have originated in East Africa $(1,4) . S$. unicorne has a wider host range and a worldwide distribution (1).

The taxonomy of the causal agents of cypress canker has been the subject of considerable debate. Guba (8) and Boesewinkel (1) differentiated between three species of Seiridium associated with cypress canker based on the presence or absence of conidial appendages, and the

Corresponding author: I. Barnes

E-mail: irene.barnes@fabi.up.ac.za

Accepted for publication 30 November 2000.

Publication no. D-2001-0108-01R

(C) 2001 The American Phytopathological Society angle of these structures relative to the main axis of the conidia. Although $S$. cardinale is distinct in having conidia with no, or very short appendages, $S$. cupressi has appendages that follow the curve of the conidia. The appendages of S. unicorne are at right angles to the main axis of the conidia. Other taxonomists believed that appendage angle was insufficient to warrant separate species and, therefore, suggested that $S$. cupressi and $S$. unicorne represent a single species $(2,13)$. It has also been suggested that only one fungus, $S$. cardinale, with variable morphology, is responsible for cypress canker (14).

Molecular studies using DNA sequence data from the ribosomal DNA (ITS1, ITS2, and 5.8S gene) regions, have been used in an attempt to resolve the taxonomic debate and infer phylogenetic relationships $(11,17)$. The sequence variation using these genes, however, failed to distinguish between the three Seiridium spp. associated with cypress canker. Thus, Viljoen et al. (17) agreed with Swart (14) in concluding that one morphologically variable species causes this disease. Based on toxins and pathogenicity, Graniti (7) has recently supported the views of Guba (8) and Boesewinkel (1) that three Seiridium spp. are associated with cypress canker.
Studies involving protein-encoding genes have successfully distinguished between closely related species that proved difficult to separate using morphological characteristics $(5,10)$. Two such genes, which are highly conserved due to their structural function and presence in all eukaryotes, are the $\beta$-tubulin and histone genes. The $\beta$ tubulin gene has been used to distinguish between fungi at all levels $(3,10,16)$. One of the histone proteins, $\mathrm{H} 3$, is particularly well conserved, especially at the amino acid level, and the presence of introns makes it a valuable taxonomic and phylogenetic tool for studying closely related organisms (12). Glass and Donaldson (6) constructed sets of primers to amplify the B-tubulin and the histone genes. These primers were designed from regions that have been shown to be highly conserved among all eukaryotes. They have been useful in amplifying DNA from filamentous ascomycetes and deuteromycetes with ascomycete affiliations.

There are strong arguments to support the existence of a single morphologically variable species of Seiridium causing cypress canker $(14,17)$. Nevertheless, there are equally good reasons to believe that more than one species causes this disease $(1,7,8)$. The aim of this study was to compare isolates of Seiridium associated with cypress canker, based on $\beta$-tubulin and histone gene sequences.

\section{MATERIALS AND METHODS}

Fungal isolates. Fourteen isolates of Seiridium from different hosts and geographic locations were used in this study (Table 1), including authenticated isolates of $S$. cardinale from Italy, New Zealand, and Chile; $S$. unicorne from New Zealand, Portugal, and South Africa; and S. cupressi from Greece and New Zealand. Isolate CMW 5596, with appendaged conidia and thus representing either $S$. unicorne or $S$. cupressi, was collected in South Africa from a diseased $C$. sempervirens tree. $S$. papillatum Z. Q. Yuan and S. eucalypti Nag Raj, both isolated from Eucalyptus delegatensis R. Baker in Australia, were included as outgroups in the phylogenetic analyses $(19,20)$.

Cultures were grown on potato dextrose agar (PDA) (Biolab, Auckland, NZ) (39 g per liter) and incubated at $21^{\circ} \mathrm{C}$ for 2 weeks. Mycelial strands of each isolate 
were transferred to Erlenmeyer flasks containing $50 \mathrm{ml}$ of malt extract broth $(2 \%$, Biolab), and incubated at $25^{\circ} \mathrm{C}$ for 10 days in a shaking incubator. The mycelium was harvested by filtration (Whatman No. 1), frozen $\left(-20^{\circ} \mathrm{C}\right)$ and lyophilised.

DNA extraction. Lyophilised mycelium was ground to a fine powder in liquid nitrogen. Approximately $0.5 \mathrm{ml}$ of the ground mycelium was suspended in $800 \mu \mathrm{l}$ of extraction buffer ( $200 \mathrm{mM}$ Tris- $\mathrm{HCl} \mathrm{pH}$ 8.0, $250 \mathrm{mM} \mathrm{NaCl}, 25 \mathrm{mM}$ EDTA pH8.0, $0.5 \%$ SDS). Phenol:chloroform (5:3) was added to the suspension and this was centrifuged $(13,000 \mathrm{rpm}, 60 \mathrm{~min})$. The aqueous phase was transferred to clean Eppendorf tubes and a chloroform extraction $(400 \mu \mathrm{l})$ was performed until a clear interface was obtained. Nucleic acids were precipitated with 0.1 vol $3 \mathrm{M} \mathrm{NaAc}(\mathrm{pH}$ 5.5) and 2 vol absolute ethanol, collected by centrifugation $(13,000 \mathrm{rpm}, 30 \mathrm{~min})$, and washed with $70 \%$ ethanol. The ethanol was removed and the DNA pellets dried under vacuum. The DNA was re-suspended in $50 \mu \mathrm{l}$ sterile water. RNase $(10 \mathrm{mg} / \mathrm{ml}$, Roche Molecular Biochemicals) was added to digest the RNA and the solution incubated for $2 \mathrm{~h}$ at $25^{\circ} \mathrm{C}$. A $1 \%$ agarose gel was run to determine the presence and integrity of the DNA.

Polymerase chain reaction (PCR) amplification. The $\beta$-tubulin gene was amplified using the forward primer $\mathrm{Bt} 2 \mathrm{a}$ and the reverse primer $\mathrm{Bt} 1 \mathrm{~b}(6)$. The histone gene fragment was amplified with forward primer $\mathrm{H} 3-1 \mathrm{a}$ and reverse primer $\mathrm{H} 3-1 \mathrm{~b}$
(6). PCR was performed in $50 \mu \mathrm{l}$ reactions, consisting of DNA template (1 ng), Expand $\mathrm{HF}$ buffer containing $1.5 \mathrm{mM} \mathrm{MgCl}_{2}$ (supplied with the enzyme), Expand High Fidelity PCR System enzyme mix (1.7 U) (Roche Molecular Biochemicals, Alameda, CA), $0.2 \mu \mathrm{M}$ of each primer and $0.2 \mathrm{mM}$ of each dNTP. An initial denaturation step of 2 min at $96^{\circ} \mathrm{C}$ was performed and subsequent cycles included: $30 \mathrm{~s}$ at $94^{\circ} \mathrm{C}, 30 \mathrm{~s}$ at $55^{\circ} \mathrm{C}$ and $1 \mathrm{~min}$ at $72^{\circ} \mathrm{C}$. These steps were carried out for 45 cycles with an added $5 \mathrm{~s}$ extension period after the first 10 cycles. A final step of $10 \mathrm{~min}$ at $72^{\circ} \mathrm{C}$ was performed to ensure complete elongation of the fragments. DNA was visualized on $2 \%$ agarose gels stained with ethidium bromide under UV illumination. Amplicons were purified using the Magic PCR Preps Purification System (Promega, Madison, WI).

DNA sequencing and analysis. PCR products were sequenced in both directions using an ABI PRISM 377 Autosequencer (Perkin-Elmer Applied BioSystems, Foster City, CA). DNA sequencing reactions were carried out with a ABI PRISM Big Dye Terminator Cycle Sequencing Ready Reaction Kit (Perkin-Elmer Applied BioSystems) according to the manufacturers protocol. The $\beta$-tubulin PCR amplicon was sequenced with the primers used for PCR as well as two additional, internal primers, Bt1a and Bt2b (6) The histone PCR amplicon was sequenced with primers $\mathrm{H} 3-1 \mathrm{a}$ and H3-1b (Fig. 1).

Sequences were aligned manually by inserting gaps and translated into amino acid sequences using Sequence Navigator version 1.0.1 (Perkin-Elmer Applied BioSystems). DNA sequences were analysed using Phylogenetic Analysis Using Parsimony (PAUP) 4.0 and other methods (15). Missing data were treated as a fifth character (new state). All characters were given equal weight. The heuristic search option (based on parsimony) with random stepwise addition and tree bisection reconnection (TBR) as the swapping algorithm, was used to construct the phylogram. The saving of all multiple equally parsimoniou trees (MULPAR) effect was incorporated and branches collapsed if they equalled zero. Tree length distribution of 100 randomly generated trees for analysis was evaluated to assess signal (9). Confidence levels of the branching points were determined using 1,000 bootstrap replicates. $S$. papillatum was used as the outgroup and was treated as a monophyletic sister group to the ingroup. A maximum likelihood search was included to determine the transition-transversion ratio for the data set.

\section{RESULTS}

Using primers Bt1a and Bt1b, approximately 440 bp was sequenced. This region contained an exon of $141 \mathrm{bp}$, an intron of $56 \mathrm{bp}$, followed by an exon of $276 \mathrm{bp}$ (Fig. 1). A total of 397 to $399 \mathrm{bp}$ was sequenced using primers Bt2a and $\mathrm{Bt} 2 \mathrm{~b}$. This region consisted of an intron of between 110 and $112 \mathrm{bp}$, an exon of 42 $\mathrm{bp}$, an intron of $64 \mathrm{bp}$ and finally an exon of $181 \mathrm{bp}$ (Fig. 1).

Table 1. Seiridium isolates for which $\beta$-tubulin and histone H3 sequence data were generated

\begin{tabular}{|c|c|c|c|c|c|c|}
\hline$\overline{\text { Species }}$ & Isolates $^{\mathbf{a}}$ & Host & Origin & Collector & B-tubulin ${ }^{b}$ & Histone $^{b}$ \\
\hline S. cardinale & $\begin{array}{c}\text { CMW 5444 } \\
\text { (CBS 522.82) }\end{array}$ & Cupressus sempervirens & New Zealand & H. Boesewinkel & $\begin{array}{l}\text { AF320499 } \\
\text { AF320500 }\end{array}$ & AF275964 \\
\hline S. cardinale & CMW 1644 & Cupressus sp. & Italy & A. Graniti & $\begin{array}{l}\text { AF320497 } \\
\text { AF320498 }\end{array}$ & AF275963 \\
\hline S. cardinale & CMW 1645 & Cupressus sp. & Italy & A. Graniti & $\begin{array}{l}\text { AF320501 } \\
\text { AF320502 }\end{array}$ & AF275965 \\
\hline S. cardinale & CMW 2133 & Cupressus sp. & Chile & M. Wingfield & $\begin{array}{l}\text { AF320503 } \\
\text { AF320504 }\end{array}$ & AF275966 \\
\hline S. unicorne & $\begin{array}{c}\text { CMW } 5443 \\
\text { (CBS 538.82) }\end{array}$ & Cryptomeria japonica & New Zealand & H. Boesewinkel & $\begin{array}{l}\text { AF320493 } \\
\text { AF320494 }\end{array}$ & AF275961 \\
\hline S. unicorne & CMW 1648 & Cupressus sp. & Portugal & A. Graniti & $\begin{array}{l}\text { AF320483 } \\
\text { AF320484 }\end{array}$ & AF275956 \\
\hline S. unicorne & CMW 1649 & Cupressus sp. & Portugal & A. Graniti & $\begin{array}{l}\text { AF320481 } \\
\text { AF320482 }\end{array}$ & AF275955 \\
\hline S. unicorne & CMW 420 & Cupressus macrocarpa & New Zealand & S. Chou & $\begin{array}{l}\text { AF320487 } \\
\text { AF320488 }\end{array}$ & AF275958 \\
\hline S. unicorne & CMW 805 & Cupressus lusitanica & South Africa & M. Wingfield & $\begin{array}{l}\text { AF320485 } \\
\text { AF320486 }\end{array}$ & AF275957 \\
\hline S. cupressi & $\begin{array}{c}\text { CMW } 5282 \\
\text { (ATCC 48158) }\end{array}$ & Cupressocyparis leylandii & New Zealand & H. Boesewinkel & $\begin{array}{l}\text { AF320489 } \\
\text { AF320490 }\end{array}$ & AF275959 \\
\hline S. cupressi & CMW 1646 & Cupressus sp. & Greece & A. Graniti & $\begin{array}{l}\text { AF320491 } \\
\text { AF320492 }\end{array}$ & AF275960 \\
\hline S. cupressi & CMW 5596 & Cupressus sempervirens & South Africa & I. Barnes & $\begin{array}{l}\text { AF320495 } \\
\text { AF320496 }\end{array}$ & AF275962 \\
\hline S. papillatum & $\begin{array}{c}\text { CMW 5302 } \\
\text { (CBS 340.97) }\end{array}$ & Eucalyptus delegatensis & Australia & Z. Q. Yuan & $\begin{array}{l}\text { AF320507 } \\
\text { AF320508 }\end{array}$ & AF275968 \\
\hline S. eucalypti & $\begin{array}{c}\text { CMW 5303 } \\
\text { (CBS 343.97) }\end{array}$ & Eucalyptus delegatensis & Australia & Z. Q. Yuan & $\begin{array}{l}\text { AF320505 } \\
\text { AF320506 }\end{array}$ & AF275967 \\
\hline
\end{tabular}

${ }^{a}$ ATCC $=$ American Type Culture Collection; CBS = Centraalbureau voor Schimmelcultures; CMW = Culture collection of the Forestry and Agricultural Biotechnology Institute (FABI), University of Pretoria, South Africa.

${ }^{\mathrm{b}}$ Sequences are deposited in GenBank. 
All 14 of the Seiridium B-tubulin genes were missing an intron (E) that is present in $N$. crassa and other eukaryotes (6) (Fig. $1)$. The two separate regions of the sequenced B-tubulin gene were combined in the analysis. A total of 883 aligned characters with 734 constant, 87 parsimonyuninformative, and 62 parsimonyinformative, were obtained. Two most parsimonious trees were generated after a heuristic search based on parsimony. These trees had similar topologies, but differed in branch lengths and one was chosen for presentation (Fig. 2). The tree length was 176 steps, consistency index (CI) and retention index (RI) was 0.909 and 0.907 respectively with a gl value of -1.035 . The trasition-transversion ratio for the B-tubulin data set was 2.32.

The histone gene sequences for the Seiridium isolates consisted of an intron of between 120 to 145 bases flanked by exons of 120 and 150 bases (Fig. 1). A total of 430 characters were used in the phylogenetic analysis with 51 informative, 68 uninformative, and 311 constant. Two most parsimonious trees were generated after a heuristic search based on parsimony. The tree chosen for presentation (Fig. 2) had a length of 161, CI of 0.894, RI of 0.899, and a gl value of -0.730 . The trasitiontransversion ratio for the histone data set was 1.31. Coding regions of both the Seiridium B-tubulin and histone genes were highly conserved and no deletions or insertions were observed.

The phylogram generated from the partial B-tubulin sequences of the representative Seiridium isolates showed two major clades (A and B). Major clade A contained one $S$. unicorne isolate from South Africa and two from Portugal, strongly associating with $S$. eucalypti from Australia with a $100 \%$ bootstrap value. Clade $\mathrm{B}$ was divided into two sub-clades $\left(\mathrm{B}_{1}\right.$ and $\left.\mathrm{B}_{2}\right)$. Sub-clade $\mathrm{B}_{1}$ was made up of both $S$. unicorne and $S$. cupressi isolates with a $97 \%$ unity. Sub-clade $\mathrm{B}_{2}$, incorporated all the isolates of $S$. cardinale that were sequenced. They were resolved into their own clade with a $100 \%$ bootstrap value. The phylogenetic tree generated from the histone gene sequences (Fig. 2) resulted in a similar topology to that generated from B-tubulin gene sequences.

\section{DISCUSSION}

Using sequence data from two different protein coding genes, we have shown that three distinct species of Seiridium are responsible for the serious tree disease known as cypress canker. These results are in contrast to the view that only one morphologically variable species of Seiridium causes the disease $(14,17)$. The results do, however, support morphological $(8,1)$ and biochemical (7) investigations based on appendage angle and toxin production, that $S$. cardinale, S. unicorne, and S. cupressi represent distinct taxa.

$S$. unicorne and $S$. cupressi were thought to be synonyms of each other $(2,13)$, due to the fact both have been found associated with cankers on Cupressaceae and both have appendaged conidia that are difficult to distinguish from each other. Other criteria such as pathogenicity and host range, however, show clear differences. S. cu- pressi is considered an aggressive pathogen, causing major pandemics especially in Europe on Cupressus spp. (7). Unlike $S$. cardinale and $S$. cupressi, the host range of $S$. unicorne is not restricted to Cupressaceae, but includes various hosts belonging to eight families $(1,7)$. S. unicorne is only mildly pathogenic and lacks the production of the toxins associated with $S$. cupressi and $S$. cardinale (7). This is consistent with the fact that it is a minor component of cypress canker disease. Results of our study, including cultures identified in Europe as typical of $S$. unicorne, show that this fungus represents a distinct taxon (Clade A, Fig. 2). It is very different from the other two species believed to be the major causal agents of cypress canker.

$S$. eucalypti has a similar pathology but is only slightly morphologically different from $S$. unicorne and was initially included in this study as an outgroup. This fungus, however, grouped extremely closely with S. unicorne (Clade A, Fig. 2), and probably represents a synonym of the latter fungus. This would be consistent with the fact that $S$. eucalypti is a mild pathogen (20) and $S$. unicorne has a wide host range (1). Our results thus support the view that $S$. unicorne is a fungus with a wide host range that extends beyond the Cupressaceae.

Because S. cupressi and S. unicorne are virtually indistinguishable based on morphology, the taxonomic treatment of these species has been very complex. Boesewinkel's suggestion (1) that the orientation of appendages is a characteristic that can be used to differentiate between the two fungi, was not widely accepted (2). Indeed,

\section{A) Seiridium B-tubulin gene}

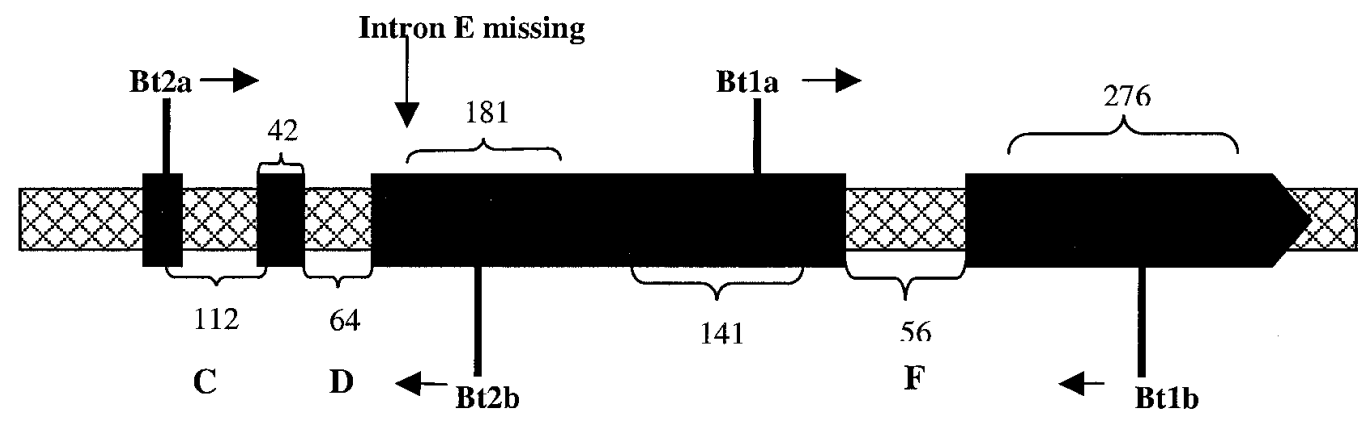

B) Seiridium histone $\mathrm{H3}$ gene

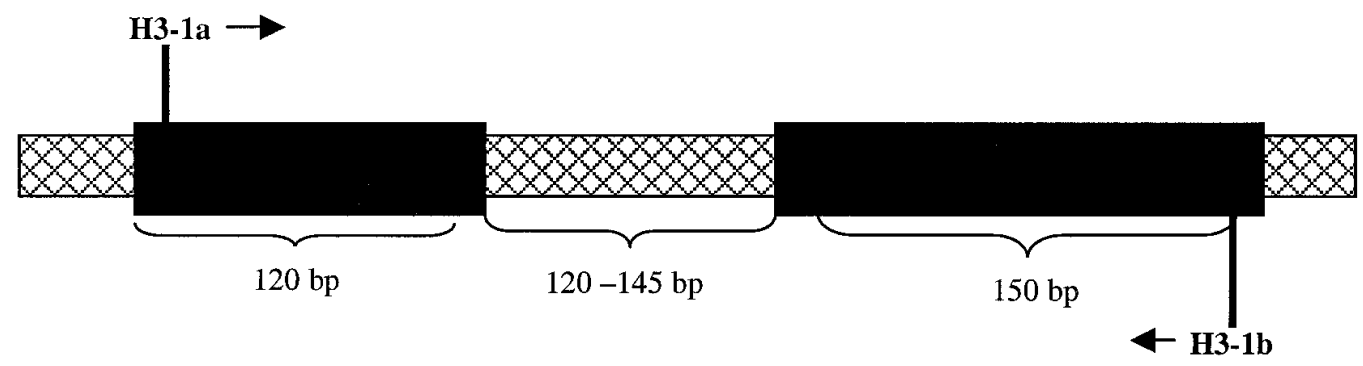

Fig. 1. A, Partial B-tubulin. B, histone gene for Seiridium spp. included in this study. Black boxes indicate the exons and meshed boxes indicate the introns. The lengths of the introns are indicated in the diagram as well as the position of the primers used. 
many isolates in culture collections, originating from cankers on Cupressus spp. have been labeled as $S$. unicorne, but probably represent $S$. cupressi. This is also true of two isolates used in the present study, which were labeled as S. unicorne, but probably represent $S$. cupressi. $S$. unicorne isolate CMW 420 was collected by Chou (2), who did not distinguish between S. unicorne and S. cupressi. Ironically, the other isolate of S. unicorne, (CMW 5443), also from New Zealand, was collected by Boesewinkel who believed he could distinguish between the species based on orientation of conidial appendages.

Boesewinkel (1) published a schematic diagram of the appendage types of three cypress canker species. This diagram (redrawn in Fig. 3) shows that our isolates, CMW 5443 and CMW 420, identified based on appendage morphology, could easily have been misidentified. It is highly likely that these isolates from New Zealand, represent the fungus known as $S$. cupressi. Sub-clade $\mathrm{B}_{1}$ could, therefore, represent the important appendaged, cypress canker pathogen known as $S$. $\mathrm{cu}$ pressi. The South African isolate collected from an infected cypress tree also falls within this clade. Although it has not been

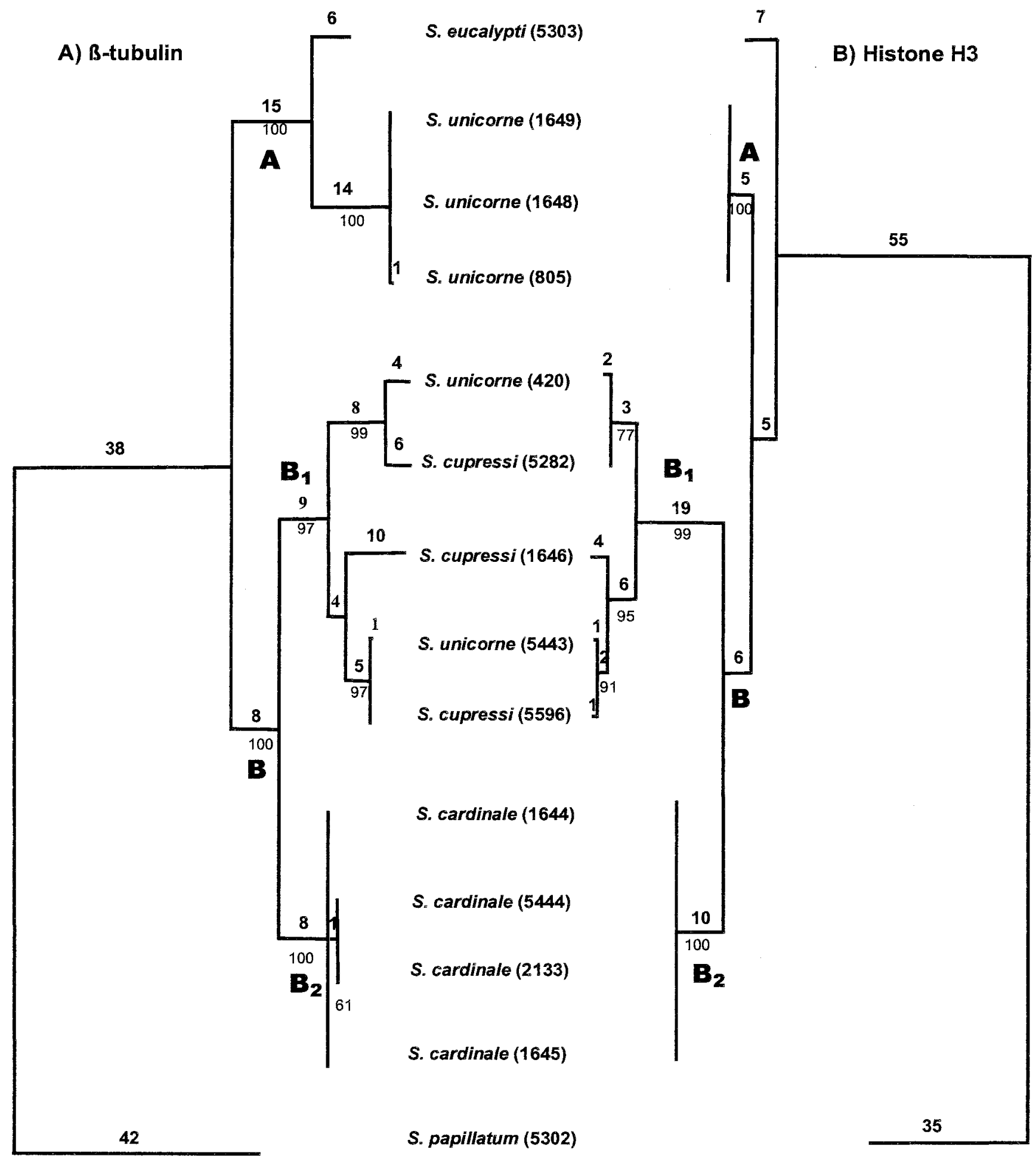

Fig. 2. Phylogenetic tree of A, B-tubulin; and $\mathbf{B}$, histone H3 sequences. The tree was produced using the Heuristic search option in PAUP 4 with Tree Bisection Reconnection. The tree is rooted with Seiridium papillatum (5302) as the outgroup. Branch lengths are shown above branches and the bootstrap confidence values below the branches. Isolate numbers are those indicated in Table 1. Isolates CMW 420 and CMW 5443 are believed to be S. cupressi. 

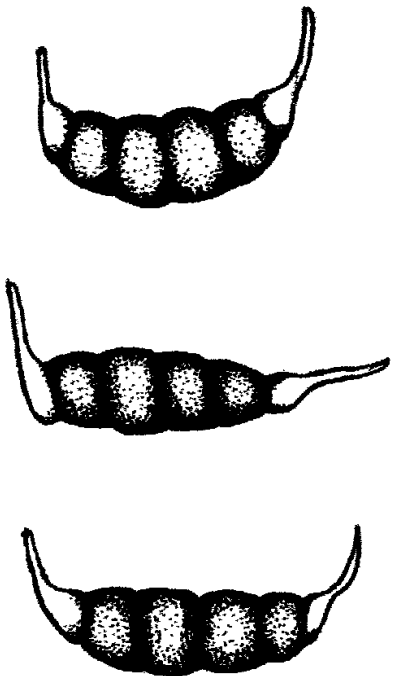
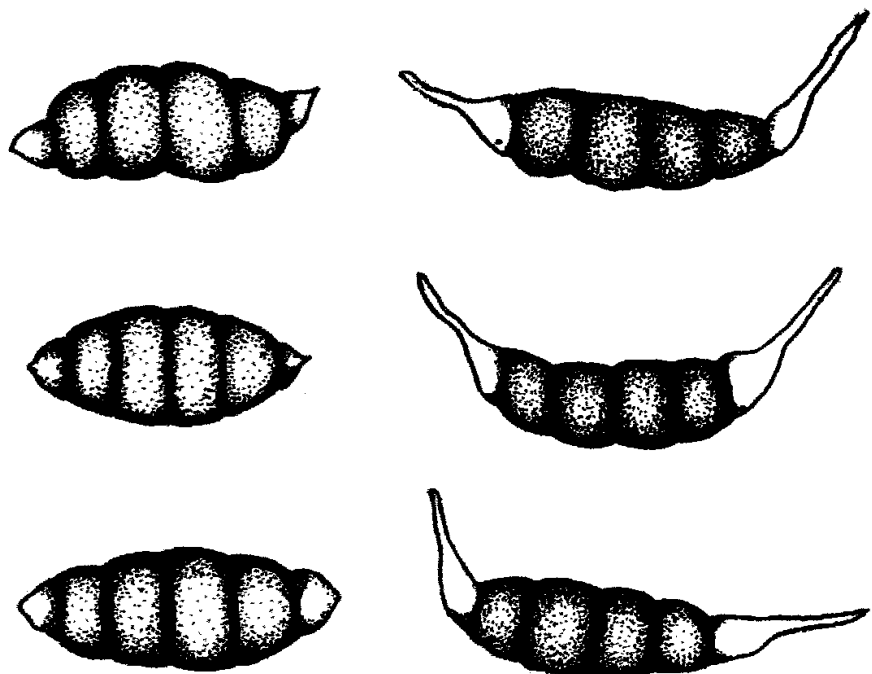

$\mathbf{A}$

B

C

Fig. 3. Conidia of the three species causing cypress canker in New Zealand (redrawn from Boesewinkel 1983). A, Seiridium unicorne; B, S. cardinale; and C, $S$. cupressi.

classified morphologically, the orientation of its conidial appendages closely resembles that of other $S$. cupressi isolates.

S. cardinale has conidia without appendages. Therefore, it differs markedly from $S$. cupressi. The fact that these two fungi reside in a single, well-resolved clade is contrary to expectations based on morphology. Specific pathogenicity to Cupressus and not the presence or absence of conidial appendages appears to be the dominant factor unifying this group. Distinguishing between these two important pathogens will now be simple, although weakly pathogenic isolates with appendages might represent those of $S$. unicorne. Molecular techniques represent the best route to identify them.

$S$. papillatum was ultimately chosen as the outgroup for this study. This fungus differs markedly from the other species in the genus by its very short, papillate conidial appendages on large, ellipsoid to subcylindrical, striate conidia (19). Molecular data confirmed its unique nature. It is, therefore, a suitable outgroup to use for comparison of relatedness among the different cypress canker species.

Seiridium canker is one of the most important and damaging diseases of trees in the world (7). As Granitti (7) has suggested, two distinct pathogens are responsible for this disease. It is important to be able to identify these pathogens with confidence. Previous studies using sequence data based on the ribosomal DNA (ITS1, ITS2, and $5.8 \mathrm{~S}$ gene) regions $(11,17)$ have not made this possible. In this study, we have shown that sequence data from either the B-tubulin or Histone $\mathrm{H} 3$ gene has a high resolution. It not only allows us to distinguish between the three Seiridium species associated with cypress canker, but also between those that are highly pathogenic ( $S$. cardinale and $S$. cupressi) and the weakly pathogenic $S$. unicorne. Using the sequence data presented in this study, it should be possible to develop more tools such as those using restriction enzyme digests and RFLP's for the rapid identification of the cypress canker pathogens.

\section{ACKNOWLEDGMENTS}

We thank the National Research Foundation (NRF) and the members of the Tree Pathology Cocorporation Program (TPCP), for their financial support. We also acknowledge colleagues and culture collections that provided cultures essential to the completion of this study.

\section{LITERATURE CITED}

1. Boesewinkel, H. J. 1983. New records of the three fungi causing cypress canker in New Zealand, Seiridium cupressi (Guba) comb. nov. and S. cardinale on Cupressocyparis and S. unicorne on Cryptomeria and Cupressus. Trans. Br. Mycol. Soc. 80:544-547.

2. Chou, C. K. S. 1989. Morphological and cultural variation of Seiridium spp. from cankered Cupressaceae hosts in New Zealand. Eur. J. For. Pathol. 19:435-445.

3. Edlind, T. D., Li, J., Visvesvara, G. S., Vodkin, M. H., McLaughlin, G. L., and Katiyor, S. K. 1996. Phylogenetic Analysis of BTubulin Sequences from Amitochondrial Protozoa. Mol. Phylogenet. Evol. 5:359-367.

4. Fuller, C. E. K., and Newhook, F. J. 1954. A Report on Cypress Canker in New Zealand. N. Z. J. Agric. 88:211-220.

5. Geiser, D. M., Frisvad, J. C., and Taylor, J. W. 1998. Evolutionary relationships in Aspergillus section Fumigati inferred from partial Btubulin and hydrophobin DNA sequences. Mycologia 90:831-845.

6. Glass, N. L., and Donaldson, G. C. 1995. Development of Primer Sets Designed for Use with the PCR To Amplify Conserved Genes from Filamentous Ascomycetes. Appl. Environ. Microbiol. 61:1323-1330.

7. Graniti, A. 1998. Cypress Canker: A Pan- demic in Progress. Annu. Rev. Phytopathol. 36:91-114.

8. Guba, E. F. 1961. Monograph of Monochaetia and Pestalotia. Harvard Univ. Press. Cambridge, MA.

9. Hillis, D. M., and Huelsenbeck, J. P. 1992. Signal, noise, and reliability in molecular phylogenetic analysis. J. Hered. 83:189-195.

10. O'Donnell, K., Cigelnik, E., and Nirenberg, H. I. 1998. Molecular systematics and phylogeography of the Gibberella fujikuroi species complex. Mycologia 90:465-493.

11. Roux, J. 1996. Molecular comparison of a Seiridium species from Acacia mearnsii with the cypress canker pathogens. Pages 139-158 in M.S. thesis. Univ. of Orange Free State, South Africa.

12. Steenkamp, E. T., Wingfield, B. D., Coutinho, T. A., Wingfield, M. J., and Marasas, W. F. O. 1999. Differentiation of Fusarium subglutinans f. sp. pini by Histone Gene Sequence Data. Appl. Environ. Microbiol. 65:34013406 .

13. Sutton, B. C. 1980. The Coelomycetes. Commonw. Mycol. Inst. Kew, UK.

14. Swart, H. J. 1973. The fungus causing cypress canker. Trans. Br. Mycol. Soc. 61:71-82.

15. Swofford, D. L. 1998. PAUP*: Phylogenetic Analysis Using Parsimony (* and Other Methods). vers: 4. Sinauer Associates, Sunderland, MA.

16. Thon, M. R., and Royse, D. J. 1999. Partial ßtubulin gene sequences for evolutionary studies in the Basidiomycotina. Mycologia 91:468-474.

17. Viljoen, C. D., Wingfield, B. D., and Wingfield, M. J. 1993. Comparison of Seiridium Isolates Associated with Cypress Canker using Sequence Data. Exp. Mycol. 17:323-328.

18. Wagener, W. W. 1939. The canker of Cupressus induced by Coryneum cardinale n. sp. J. Agric. Res. 58:1-46.

19. Yuan, Z. Q., and Mohammed, K. 1997. Seiridium papillatum, a New Species (Mitosporic Fungus) Described on Stems of Eucalypts in Australia. Aust. Syst. Bot. 10:69-75.

20. Yuan, Z. Q., and Old, K. M. 1995. Seiridium eucalypti, a potential stem canker pathogen of eucalypts in Australia. Australas. Plant Pathol. 24:173-178. 